\title{
Total parenteral nutrition in the pleural space
}

\author{
Rachel Victoria Chiumento, Joanne Frances Anderson, David George Bartle
}

Department of Paediatrics, Royal Devon and Exeter NHS Foundation Trust, Exeter, UK

\section{Correspondence to} Dr Rachel Victoria Chiumento, r.chiumento@nhs.net

Accepted 22 August 2018
D Check for updates

(c) BMJ Publishing Group Limited 2018. No commercial re-use. See rights and permissions. Published by BMJ.

To cite: Chiumento RV, Anderson JF, Bartle DG. BMJ Case Rep Published Online First: [please include Day Month Year]. doi:10.1136/ bcr-2018-224561

\section{DESCRIPTION}

A male infant was delivered spontaneously at $29+3$ weeks and transferred to the local neonatal unit for uplift in care. This included 24 hours of ventilation, 12 hours of dobutamine and placement of a peripherally inserted central catheter (PICC) for total parenteral nutrition (TPN). By 24 hours he was extubated onto Optiflow at $6 \mathrm{~L} /$ min and Fraction of Inspired Oxygen $\left(\mathrm{FiO}_{2}\right)$ of 0.21 . Expressed breastmilk was commenced whilst awaiting PICC placement.

A $22 \mathrm{G} 80 \mathrm{~mm}$ Leaderflex PICC was aseptically inserted on day 2 into the right antecubital fossa. The line did not bleed but flushed easily. A $0.9 \%$ sodium chloride infusion was commenced whilst awaiting confirmation of line position. Chest X-ray showed the PICC projected over the subclavian vein with mild residual airspace shadowing in both lungs (figure 1). The PICC position was felt to be acceptable when the X-ray was reviewed prospectively and retrospectively.

TPN was commenced at 16:00. At 23:00 the nurse noted the baby had increased work of breathing with an increased $\mathrm{FiO}_{2}$ from 0.21 to 0.7 -Optiflow was changed to Continuous Positive Airway Pressure (CPAP). A small swelling was noted on the right lateral chest wall which prompted immediate discontinuation of TPN and removal of the PICC.

On registrar review the baby was grunting, with recession and oxygen saturations of $92 \%$ in 0.7 $\mathrm{FiO}_{2}$ on CPAP. Clinical examination confirmed bilateral air entry and no transillumination with a cold light. A sudden deterioration led to Neopuff resuscitation. Urgent chest X-ray showed a new right-sided pleural effusion (figure 2).

The airway was secured with an endotracheal tube and ventilation improved. When lignocaine was infiltrated, a white liquid was aspirated from the pleural cavity. The consultant felt confident

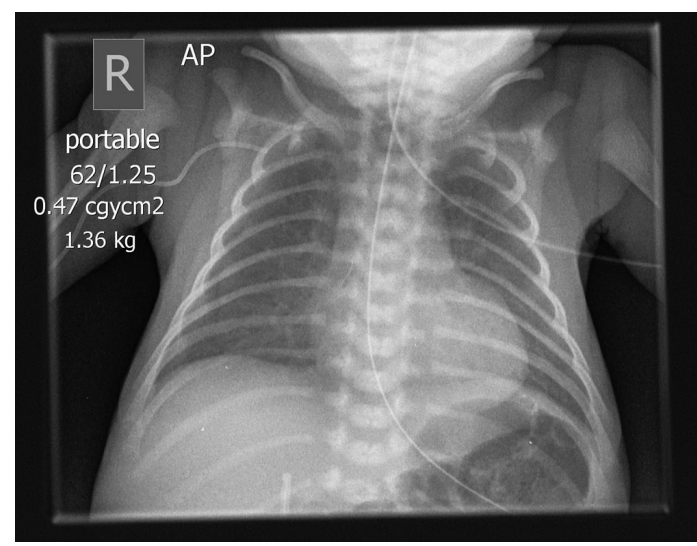

Figure 1 Chest $X$-ray showing peripherally inserted central catheter line placement. AP, anteroposterior.

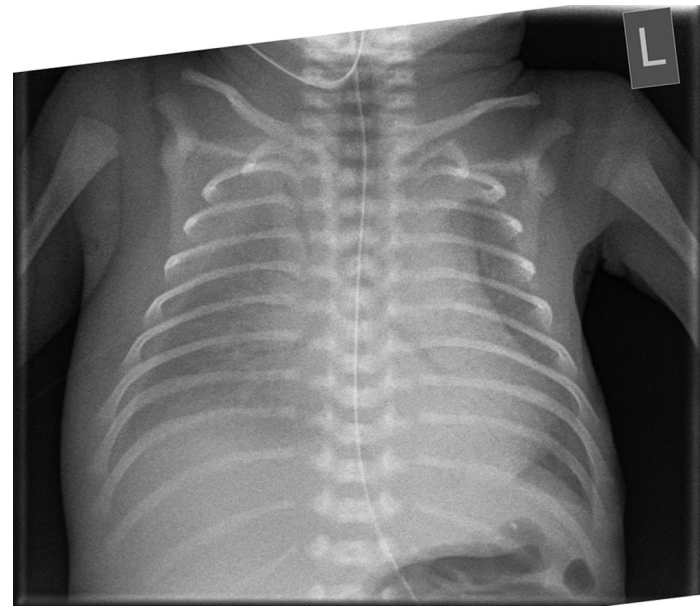

Figure 2 Chest $\mathrm{X}$-ray showing new right-sided pleural effusion.

TPN was in the chest cavity and inserted the $8 \mathrm{Fr}$ chest drain, which was uncomplicated.

From the pleural space, $20-30 \mathrm{~mL}$ of fluid was drained and second-line antibiotics were commenced. Repeat chest X-ray showed improved airspace shadowing and resolving right-sided pleural effusion (figure 3).

On day 4 an X-ray confirmed resolution of the pleural effusion and the chest drain was removed. The baby was extubated on day 5 onto Optiflow at $8 \mathrm{~L} / \mathrm{min}$. Antibiotics were discontinued following three C-reactive protein tests of $<1$ and negative blood cultures. Delivery of TPN was continued via a peripheral cannula.

Following biochemistry analysis, the pleural fluid was confirmed to be consistent with TPN contamination: visibly lipaemic, protein of $3 \mathrm{~g} / \mathrm{L}$, triglycerides of $4.40 \mathrm{mmol} / \mathrm{L}$ and creatinine of $58 \mu \mathrm{mol} / \mathrm{L}$.

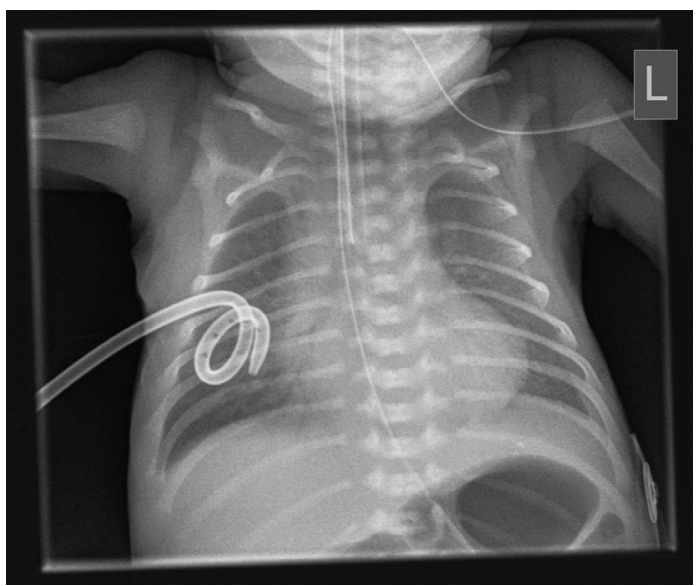

Figure 3 Chest X-ray showing right-sided chest drain. 


\section{Learning points}

To image intermediate peripherally inserted central catheter (PICC) line placement using ultrasound or X-ray with contrast to identify possible malposition prior to using the line.

- To ensure PICC lines are effectively secured at insertion.

- To monitor PICC line position with daily recording of the length at the insertion site and ultrasound surveillance.

On day 6 of life, the baby was fully enterally fed and self-ventilating without respiratory support.

PICCs are commonly used for delivery of TPN in neonates; the ideal PICC line position is within the region of the superior vena cava/right atrium confluence, and migration needs to be carefully monitored for. PICC lines that reside in an intermediate position (subclavian or axillary vein) are at $100 \%$ increased risk of complications, including pleural effusions, ${ }^{1}$ with the incidence of complications ranging from $0.3 \%$ to $2 \%$. $^{2}$

This patient had an intermediately placed PICC that was malpositioned despite acceptable position on chest X-ray. In future this could be identified earlier using ultrasound imaging or a contrast X-ray prior to using the line. ${ }^{3}$

Contributors Substantial contributions to the conception or design of the work, or the acquisition, analysis or interpretation of data: RVC, JFA, DGB. Drafting the work or revising it critically for important intellectual content: RVC, JFA, DGB. Final approval of the version published: RVC, DGB. Agreement to be accountable for all aspects of the work in ensuring that questions related to the accuracy or integrity of any part of the work are appropriately investigated and resolved: RVC, JFA, DGB.

Funding The authors have not declared a specific grant for this research from any funding agency in the public, commercial or not-for-profit sectors.

Competing interests None declared.

Patient consent Parental/guardian consent obtained.

Provenance and peer review Not commissioned; externally peer reviewed.

\section{REFERENCES}

1 Goldwasser B, Baia C, Kim M, et al. Non-central peripherally inserted central catheters in neonatal intensive care: complication rates and longevity of catheters relative to tip position. Pediatr Radiol 2017;47:1676-81.

2 Sertic AJ, Connolly BL, Temple MJ, et al. Perforations associated with peripherally inserted central catheters in a neonatal population. Pediatr Radiol 2018;48:109-19.

3 Kumar J, K C S, Mukhopadhyay K, et al. A misplaced peripherally inserted central catheter presenting as contralateral pleural effusion. BMJ Case Rep 2018;2018:bcr-2018-224471.

Copyright 2018 BMJ Publishing Group. All rights reserved. For permission to reuse any of this content visit

http://group.bmj.com/group/rights-licensing/permissions.

BMJ Case Report Fellows may re-use this article for personal use and teaching without any further permission.

Become a Fellow of BMJ Case Reports today and you can:

- Submit as many cases as you like

- Enjoy fast sympathetic peer review and rapid publication of accepted articles

- Access all the published articles

Re-use any of the published material for personal use and teaching without further permission

For information on Institutional Fellowships contact consortiasales@bmjgroup.com

Visit casereports.bmj.com for more articles like this and to become a Fellow 